\title{
FACTORS ASSOCIATED WITH STUNTING IN CHILDREN UNDER FIVE IN KARAWANG, WEST JAVA
}

\author{
Rona Luthfi Fauziyyah'), Yulia Lanti Retno Dewi²), \\ CSP. Wekadigunawan'), BhismaMurti') \\ 1)Masters Program in Public Health, Universitas Sebelas Maret \\ ${ }^{2)}$ Faculty of Medicine, Universitas sebelas Maret
}

\begin{abstract}
Background: Despite global efforts, stunting remains a public health problem in several developing countries. It is estimated that globally in $2016,24 \%$ of children under age five were still stunted. Stunting during childhood can lead to reduced immunity, increased susceptibility to non-communicable diseases, impaired physical and mental development, and reduced productivity. This study aimed to analyze factors associated with stunting in children under five in Karawang, West Java.

Subjects and Method: A case control study was conducted in 5 community health centers in Karawang, West Java, from April to May 2018. A sample 225 children under five consisting of 75 stunted children and 150 normal children was selected by fixed disease sampling. The dependent variable was stunting. The independent variables were maternal height, low birthweight, exclusive breastfeeding, complementary feeding, and history of infectious disease. Data on children body height were measured by infantometer or microtoise. The other data were collected by questionnaire. The data were analyzed by a multiple logistic regression.

Results: The risk of stunting increased with low birthweight $(\mathrm{OR}=4.61 ; 95 \% \mathrm{CI}=$ 1.73 to $12.24 ; \mathrm{p}<0.001)$ and history of infectious illness $(\mathrm{OR}=4.77 ; 95 \% \mathrm{CI}=1.95$ to $11.69 ; \mathrm{p}=0.001)$. The risk of stunting reduced with maternal height $\geq 150$ $\mathrm{cm}(\mathrm{OR}=0.20 ; 95 \% \mathrm{CI}=0.08$ to $0.49 ; \mathrm{p}<0.001)$, exclusive breastfeeding ( $\mathrm{OR}=$ $0.39 ; 95 \% \mathrm{CI}=0.17$ to $0.88 ; \mathrm{p}=0.024)$, and appropriate complementary feeding $(\mathrm{OR}=0.24 ; 95 \% \mathrm{CI}=0.11$ to $0.54 ; \mathrm{p}=0.001)$.

Conclusion: The risk of stunting increases with low birthweight and history of infectious illness, but reduces with maternal height $\geq 150 \mathrm{~cm}$, exclusive breastfeeding, and appropriate complementary feeding.
\end{abstract}

Keywords: stunting, low birthweight, exclusive breastfeeding, complementary feeding, infectious illness

\section{Correspondence:}

Rona Luthfi Fauziyyah. Masters Program in Public Health, Universitas Sebelas Maret, Jl. Ir. Sutami No. 36 A, Surakarta 57126, Central Java.

Email: rona.luthfi@gmail.com. Mobile: +6281316970696. 